\title{
Drivers and Barriers of University Social Responsibility: Integration into Strategic Plans
}

\author{
Elva L. Ramos-Monge \\ Polytechnic University of Catalonia, Department of Management, Barcelona, Spain \\ elva.lizeth.ramos@estudiant.upc.edu \\ Xavier Llinàs-Audet \\ Polytechnic University of Catalonia, Department of Management, Barcelona, Spain \\ xavier.llinas@upc.edu \\ Jesús Barrena-Martínez \\ University of Cadiz, Department of Business Management, Faculty of Economics and Busi- \\ ness, Cadiz, Spain \\ jesus.barrena@uca.es
}

\begin{abstract}
The implementation of University Social Responsibility (USR) in its strategic plans is a subject of great social interest. However, the lack of understanding produces deficient stakeholder's engagement, obstructing USR applications and potential benefits. USR in a formal context and as part of strategy should be a path that leads to its fulfilment. A Delphi method was used and several experts have participated in it. Results show that USR is related to student's issues, among main drivers are to work under a code of ethics and acquire civic competences as a part of their vocational training. Among barriers to be involved in social responsibility activities is the lack of engagement of university community. The insufficient communication into the university community is mentioned as one of the main obstacles to incorporate USR into strategic planning. Relevance of this work relies on the holistic points of views of the results.
\end{abstract}

Keywords: University Social Responsibility, Delphi method, Strategic Management, Strategic

Plan, Stakeholders Theory.

\section{INTRODUCTION}

Nowadays, social challenges lead universities to play a critical role into society, being their actions essential in its development (UNESCO, 1998). In this context, it is necessary to rethink the Higher Education Institutions (HEI) role and its objectives (GUNI 2017). Therefore, University Social Responsibility (USR) represents a topic worthy of study, and its existence is justified from its public nature and its intrinsic responsibilities to society (Neave 2000).

Consequently, HEI management must be oriented towards fulfilling these social, environmental and economical responsibilities (Velandia \& Girotto 2015). For this reason, the ability of universities to meet the needs of stakeholders has great importance when seeking social responsibility. To achieve this commitment, it is necessary that academic authorities get engaged and be able to identify how to assist their responsibilities. 
This work aims to find the actions that universities implement to achieve USR. In this way, hypotheses related to actions that lead universities to USR and their stakeholders, barriers, and their place into strategic plan are exposed. As a method to test these hypotheses, Delphi has been applied in order to identify these actions. This method consists of doing several iterations of questionnaires to experts of the topic, being each questionnaire modified according to the feedback provided by experts in previous iterations. The objective of this method is to gain consistent consensus about an specific issue (Linstone \& Turoff 1975). The success of Delphi relies on knowledge and experience of consulted experts and the design of the questionnaire.

This study considers a panel of experts from Spanish and Mexican universities. In the first round, the panel was composed by six Spanish experts, who refined the questionnaire to be applied in the second round. Next, in the second round, twenty one experts participated; four of them were Mexican and the rest were Spanish. The questionnaire uses a Likert scale and open questions related to these areas: 1) university management, 2) academic training, 3) responsible research, 4) university staff, and 5) social development. The first round consisted of 84 questions and the second of 69 questions. Every question deals with ethical and sustainable actions taken from the literature related to social responsibilities. Alpha of Cronbach was used to validate each area of the questionnaire and the results show that there exists good correlation between the items.

Results had shown that students play as a focal stakeholder related to USR, their training linked to an ethical way to investigate and work under a code of ethics are among top priorities to achieve USR. Lack of communication and engagement of university community are barriers to USR. Finally, results suggest that USR should be inherent into university mission.

The document is structured as follows: Section 1 develops the research gap, theoretical framework on USR and its drivers, strategic management/strategic plan, USR into the strategy, stakeholder theory, together with hypotheses being presented in this section. Section 2 presents the method, procedure, panels of experts, instrument and validation of the questionnaire. Section 3 shows and discusses the results obtained. Finally, Section 4 presents the conclusions.

\subsection{Research Gap}

Society is currently experiencing an economic and social crisis, which motivates many organizations to reorient their roles. This is the case of HEI, where social responsibility increases its relevance due to its strong engagement to all its stakeholders. However, misunderstanding the USR concept could affect its implementation into university activities. Also, there is a lack of studies focused on the social responsibility of public administration (Dumay et al. 2010; Navarro-Galera et al. 2014), which may be related to the intrinsic mission of public organizations to meet social demands (Vázquez et al. 2016). Nevertheless, process standardization helps the USR implementation (ISO 26000 2014; GRI 1997). For this reason, implementing strategies related to USR are necessary to understand it in a greater way in order to: 1) knowing the focal actions that drive to the achievement of USR and the main barriers to develop these actions, and 2) identifying how USR should be implemented into the strategic plans. 


\subsection{Theoretical Framework}

There are important concepts and background related to USR that should be introduced for a proper understanding of this work: USR, strategic management and strategic plan, and the stakeholder theory.

\subsubsection{University Social Responsibility and its drivers}

Social responsibility into public administration institutions (Hernández 2007; Navarro et al. 2010), and particularly inside HEI (Atakan \& Eker 2007; Brown \& Cloke 2009; Vasilescu et al. 2010) has been hardly studied in recent years, in order to react responsibly to social demands, due to its social inherent engagement. In this line, expectations of social responsibility are more related to public organizations due to its social mission than to those organizations whose purpose is to obtain economic benefits (Vázquez et al. 2016).

The USR can be understood as a policy of ethical performance in HEI through responsible management in the university areas of teaching, research, extension and university management (Vallaeys et al. 2009). USR develops a participative dialog with society pursuing sustainable development (Linares et al. 2012). Likewise, USR is the university capacity to disseminate a set of ethics and values, leading to effective implementation of their social mission into its entire management field (Vallaeys 2008; Domínguez 2009).

To understand the USR phenomenon is necessary to considerate the approaches under which USR has been studied (Gaete 2011). First, the management approach analyses the impact of all university activities, which are justified in accountability. An example is the creation of standards to create sustainability reports, which could be based on the Global Reporting Initiative (GRI). Second, the transformational approach links HEI with debate on social issues, using university tools such as research and training, thus benefiting from their social leadership (Kliksberg 2009; Chomsky et al. 2002; UNESCO 1998b). Third, the normative approach refers to university dissemination of values to society through national and international networks, for example the Principles for Responsible Management of Education (PRME), and Global University Network for Innovation (GUNI 1999), which disseminate values to society.

This research is based on the management approach as it is closest to strategic focus. Since USR is the responsible management aimed to meet the needs of university stakeholders, it is necessary to explain some of the main drivers to USR:

- Drivers to responsible university management. They are those related to communicate main activities making use of transparency, this could be done by sustainability reports based on GRI (GRI 1997). Also a responsible management promotes communication among stakeholders, which is a key for successful strategies (Peng \& Littlejohn 2001). This management should meet social and environmental responsibilities (PRME 2007; GRI 1997), and promote gender equality (Jacobs 1996; Teelken \& Deem 2013).

- Drivers to responsible management of staff. Examples of these drivers are training of university staff, due to its positive effect on university community (Gibbs \& Coffey 2016), also, this training seems to have a positive influence on the good attitudes of academic staff and researchers (Murray \& Lombardi 2010). Likewise, cultural activities and attraction of new talent to university (Araya \& Peters 2010) are good examples. 
- Drivers to responsible academic training. They are those that develop responsible capabilities and competences among students (PRME 2007). Part of the role of universities is to formulate an environmental behaviour among students, as well as to stimulate knowledge to take action (Hines et al. 1987). Another driver is volunteering, an activity that encourages work-integrated learning, experiential learning and service-learning (Cronje 2015). Nevertheless it is an issue worthy of further research (Francis 2011). Furthermore, teaching and learning about new businesses could be considered a driver to USR, since promotion to entrepreneurial activities could benefit society, reducing informal economy's activities (Williams et al. 2016), and, above all, because universities are identified as the driver of an entrepreneurial society (Ratten 2017). However, there is a need to promote business skills, because entrepreneurs do not have them. In this sense, universities play an essential role (Gnyawali \& Fogel 1994). Thus, increasing the quantity and quality of courses on entrepreneurship may lead to an improvement of those skills and could have a positive influence on students who had not previously thought of becoming entrepreneurs (Palalić et al. 2017).

- Drivers to responsible research. They are mainly related to the ethical way to investigate and to produce useful research to society, helping to solve community problems (Owen et al. 2012; PRME 2007; UNESCO 1998a; GUNI 2017).

- Drivers to responsible social development. They are those that universities implement in order to achieve a more inclusive society (GUNI 2017; De la Cruz \& Sasia 2008; UNESCO 1998a). Actions like the participation in regional development and the association with local organizations are good examples. In the same way as companies are called to act in issues such as poverty, social justice and climate change (Rexhepia et al. 2013), this study takes those drivers to university activity. Also, the role of helping transformational relationships among stakeholders in the economic and developmental process (Morris et al. 2011) is part of these drivers.

To sum up, all these drivers are examples of actions that a HEI carries out in order to meet the needs and expectations of its stakeholders.

\subsubsection{Strategic Management and Strategic Plan}

In order to reach a transversal and formal application of USR, the organization of universities must be efficient and careful to considerate stakeholders' expectations and demands. This task belongs to strategic management, which includes a technical team controlling activities related to HEI work by using the strategic plan as a principal management tool (Llinàs et al. 2011).

In this sense, it is crucial to consider a planning process, which begins with decision making taken by the governance, this includes "thinking" as strategy diagnosis and formulation and "doing" by implementing those strategies requiring resources, organization, processes, actions, tactics, coordination and management, and strategic commitments as a key aspect. Finally, "learning" takes place, embracing the evaluation, the review and the improvement of all the planning. These three component of strategic management are achieved with communication (Velandia \& Girotto 2015). 
In this planning process, strategic decisions are taken. These decisions are characterized by their long term focus, global scope, and proposing significant changes that leads to complex activities (Planellas \& Muni 2015).

In the field of Corporate Social Responsibility (CSR), strategies must be adapted to service social needs (Porter \& Kramer 2011). To develop those strategies it is needed for leaders to be able to understand organizational impacts, inside or outside the organization (Andriof \& McIntosh 2001). Thus, CSR is becoming a part of the companies, especially when they search for greater value and competitiveness (Rexhepia et al. 2013). On HEI, the core of strategic decisions is the social mission, as the reason of being of each university, the vision, what HEI wants to become in the future and values, how universities want to do all those actions.

For the development of strategic planning it is necessary to study the HEI environment, for this, internal strength and weakness, external opportunity or threat (SWOT) are models that help to combine external and internal analyses. Although there is not enough research about implementation of social responsibility into strategic management (Sánchez \& Mainardes 2016), the success of USR depends on its implemented strategies. These strategies should include mission, goals, objectives, lines of action and other components that constitute a strategic plan (Quinn 1980). In this way, the perspective of this work is the study of the USR within the strategic plan.

It is important to highlight that each HEI carries out its own strategies differentiated by their particular environment, with specific resources and needs.

Moreover, the strategic plan allows to take advantage of opportunities by using resources strategically and help the development of future plans (Hunt et al. 1997). Also, it provides a sense of autonomy, facilitating the decision-making process and improving communication (Lumby 1999), helping to implement and control activities that drive to USR.

\subsubsection{University Social Responsibility into the strategy}

The strategic plan facilitates the development of the strategy. As explained above, this plan involves thinking, doing and learning. In this section the focus will be on doing, which includes:

- Implementation

- Communication

- Alignment

Doing, is often the most difficult step, as it is the achievement of the objectives and strategy execution (Hrebiniak 2007). Strategic implementation requires more people, and therefore, more special commitment of people in charge (Hrebiniak 2007), and as a cycle, commitment is achieved with an efficient doing (Velandia \& Girotto 2015).

Commitment is the involvement and dedication of all areas in terms of strategic decisions (Wooldridge \& Floyd 1990), it evaluates the degree of willingness to focus efforts and resources on accepting and implementing the strategies. Its importance relies on strategy implementation which may fail by lack of support and commitment of university community (Velandia \& Girotto 2015).

Nevertheless, commitment can be obstructed by factors as lack of communication, which has been identified as the most frequent barrier to an effective strategy implementation (Alexander 1985). Communication represents a key aspect for strategy success (Peng \& Littlejohn 2001) and increases commitment, helping strategy implementation. 
If the strategy is not clear and reliable, people will not understand it, causing lack of commitment on its realization. For this reason, academic authorities, such as managers, should contribute to emotional and intellectual connection among stakeholders fostering employee engagement (Gibbons 2006).

\subsubsection{Stakeholder Theory}

The achievement of a successful social responsibility strategy needs the engagement and satisfaction of all of the stakeholders immersed in corporate actions. The aim of social responsibility is to respond opportunely to all the actors involved in the university activity, those who participate in the HEI work and those who are influenced by this task. In this sense, stakeholders theory helps to explain and support USR (Larrán \& Andrades 2015). A common classification of these groups is based on the internal or external membership of the organization (Burrows 1999; Jongbloed et al. 2008). Also, Reavill (Reavill 1998) classified stakeholders as:

- $\quad$ Students and families;

- University administrative staff and faculty members;

- Suppliers of goods and services;

- Educational sector;

- Other universities;

- Commerce and industry;

- The nation;

- $\quad$ The Government;

- Local and national taxpayers;

- Authorities and professional bodies;

Other authors classify stakeholders between their level of influence, as theory of stakeholder salience (Mitchell \& Wood 1997), distinguishing those stakeholders according to the urgency for immediate actions, the influence or power of the stakeholders in the development of concrete actions, and the legitimacy with the activities that they perform in the institution. Students, as the main client of HEI, attract special attention, this is the case of the study "University social responsibility: a student base analysis in Brazil" (Sánchez \& Mainardes 2016); which considers students as the main stakeholder. In the same vein, efforts to cover student's demands can be seen through Principles for Responsible Management of Education (PRME), which promote student's values in business schools.

Therefore, this study is an effort to include main actors that impact on university activity, such as students, professors, researchers, other staff, and society.

\subsection{Hypotheses}

It can be understood by literature review, that stakeholders expectations of universities are seen more related to educational impacts (Vázquez et al. 2016), and that principal stakeholder on HEI are students (Sánchez \& Mainardes 2016). Moreover, it seems that communication represents a main component to implement strategy (Peng \& Littlejohn 2001) and, without communication, the participation of stakeholders is obstructed. Additionally, transversal inclusion of USR into strategic planning seems to be the most accepted way to include USR. Transversal means that USR is inherent to mission and represents the 
base of decisions, taken from the strategic management. This, due to its inherent social mission (Domínguez 2009; Vallaeys 2008; Vázquez et al. 2016).

Thus, the hypotheses that support this study are listed as follows:

H1. Main drivers that experts identify as part of USR are those related to students' training.

$\mathrm{H} 2$. Barriers of the inclusion of USR on strategic planning are related with lack of university community engagement.

H3. Inclusion of USR into the university strategies is most accepted into university missions.

\section{METHOD}

Delphi method (Dalkey \& Helmer 1963) was applied to address the proposed objectives. This technique is an structure method of a group communication process, useful to solve complex issues (Linstone \& Turoff 1975). It consists of applying a series of questionnaires (hereafter rounds) to experts in a specific subject, a controlled feedback is made after each round and the objective is to gain consistent consensus about an specific issue.

Several authors consider the Delphi method may have different interpretations and applications (Keeney et al. 2001). The success of the method relies on the design of the questionnaire, and the experience and knowledge of consulted experts. In this sense, their specific qualifications and the number of participants are key aspects for the method success (Powell 2003). The number of experts could differ depending on the subject and the resources available (Delbecq et al. 1975; Fink et al. 1991; Hasson et al. 2000). Actually, the real value of this method depends on the quality of the consulted experts, rather than the number of experts.

Delphi technique is a consistent method to develop this research, due to the difficulties in quantifying the subject and because it allows a prospective analysis. In this way, this method allows to find those actions that universities could adopt to have social responsibility, to detect main obstacles to develop those actions and to include this social responsibility into the universities.

This study was developed under a deductive approach, which focuses on pre-defined theoretical categories and collected data pre-defined. Although deductive research offers orientation needed for successful research, using this approach implies risks as "circularity" (misalignment between theories used and research.) and risk of "abstract actors" (misunderstandings in the definition of the unit of analysis) (Dana \& Dumez 2015). To avoid circularity, theories used were mentioned on text and drivers to USR were well defined. To avoid abstract actors, HEI stakeholders and areas of HEI were taken as units of analysis. Results presented in this study are beyond the hypothesis proposed, since it is value-laden and may limit results (Tinker et al. 1982; Morgan 1983; Berry 1986).

Open and closed questionnaires have been applied and a holistic-inductive approach has been chosen. Holistic-inductive approaches requires a flexible design with constant evolution (Dana \& Dana 2005). In this context, objectives were not imposed since the beginning, rather efforts to understand phenomena, new questions were formulated and the first questionnaire allowed creating more accurate questions for the second questionnaire. 


\subsection{Procedure}

The construction of the Delphi method has followed a series of steps. First step was delimitation of the context, and the development of hypotheses. Next, decision to include two panels of experts, researches and academic authorities was taken to improve the study.

Then, the selection of experts (key step to method success), here, Spanish and Mexican experts were invited to participate. We contacted them and explained the complete study and tried to get their commitment to participation. Then, the process continued sending the first questionnaire, on January the $27^{\text {th }} 2017$, and the round finished on March the $21^{\text {st }} 2017$. The second round was sent on $4^{\text {th }}$ of May 2017 and finished on 14th June 2017 (to review complete process, see Figure 1). The total process lasted six months.

\subsection{Panels of experts}

Two groups of experts were requested by mail to answer the questionnaire through the institutional web of the Polytechnic University of Catalonia. The first panel was chosen principally based on their research area, quantity and quality research and they helped to refine the questionnaire. The second panel was selected according to their years of experience (average of 25 years) and position as an academic authority, the positions of experts are:

- Vice Chancellor of Social Responsibility

- University Professor

- Chancellor

- Director of the Sustainability Center

- Academic Director of Virtual Area

- Professor and Director of Graduate Area

- Director of the Department of Quality Management

- Professor and Director of Business Chair

- Responsible for Strategy

- Chancellor of Quality Management and Teaching

- Secretary of the Social Council

- Dean and Professor

- Executive Secretary

- Head of Department of University Extension and Social Service

- Director of Laboratory of Innovation and Talent Detection

The first panel was made by ten experts, obtaining responses from six of them. The second panel contained thirty experts, getting the responses from four Mexicans and seventeen Spaniards.

Both groups combine knowledge and experience, achieving heterogeneous groups which lead us to obtain a higher quality of the method as it allows to consider different perspectives (Murphy et al. 1998).

\subsection{Instrument}

The instrument was a questionnaire based on a Likert scale (Armstrong 1987) of five points and levels of importance, 1) unimportant, 2) somewhat important, 3) quite important, 4) very important and 5) extremely important. Two different questionnaires were developed for each round. In the first round, the questionnaire included a series of drivers to USR, 
taken from GRI, GUNI and UNESCO (see Table 1). On the other hand, in the second round, the questionnaire included the feedback of the first group of experts.

Both questionnaires included the key issues (see Figure 2) to achieve the same objectives. Additionally, open questions were included to allow experts to expose their knowledge and experience about more actions that lead to USR.

As part of open questions about the inclusion of USR into strategic management, experts were requested to answer about the role of USR as internal strength, internal weakness, external opportunity or external threat.

\subsection{Validation of the questionnaire}

To carry out the validation of the questionnaire, we calculated the Alpha of Cronbach to validate the internal consistency. It is applied independently to each area of the questionnaire (see Table 2) to estimate the reliability of the answers of the questionnaire through the set of items that are expected to measure the same construct. Also, the Alpha of Cronbach was calculated for the two rounds.

The reliability of the internal consistency of the questionnaire is calculated by proving that questions of the instrument measure the same construct and are highly correlated (Welch \& Comer 1988). When value of alpha is closer to 1, internal consistency of the analyzed items is higher.

The area with higher internal consistency and excellent correlation between the items in round two was "University management". On the other hand, the lowest consistency was the "Responsible research" in the second round. This result shows that the five items that were tested in the second round have a questionable degree of correlation.

\section{ANALYSIS OF RESULTS}

The analysis of results is organized in three sections. First, the methodology used to obtain the results is introduced; next, the results are presented; and finally the results are discussed.

\subsection{Methodology}

For the Delphi method, the main statistical analysis uses measures of central tendency and dispersion and the Alpha coefficient of Cronbach (García \& Suárez 2013). In this study we decide to calculate the standard deviation, which measures dispersion of values regarding to arithmetic mean. The items with the lowest standard deviation are these with a greater consensus.

For a better explanation, the Coefficient of Variation (CV) has been calculated. It expresses the standard deviation as a percentage of the arithmetic mean, showing a better percentage interpretation of the degree of variability. Thus, the lower $\mathrm{CV}$, the greater homogeneity in the values of the variable.

Equation for $\mathrm{CV}$ expressed in percentage, where $\sigma$ is the standard deviation and $\bar{x}$ is the mean, is represented as follows:

$C_{v}=\frac{\sigma}{|\bar{x}|} \cdot 100$

Its values range from 0 to 1 . Closer to zero means lower variability and reflects a compact sample. It measures the size of the standard deviation regarding the mean of the data set that is examined, and it is interpreted as Table 3 shows. 
Thus, to create the second questionnaire we selected items with CV of $20 \%$ or greater. The objective was to test them again in the second questionnaire and the rest of the items were removed. Therefore, the second questionnaire was formed by (1) the items with CV higher than $20 \%$, (2) the items suggested by experts, and (3) open questions to add more flexibility to the experts' answers.

The second questionnaire was applied to both panels. Considering that the main objective of this method is to reach the highest consensus, the Likert scale score with the highest repetition of the first round (mode) in each item was shown in the second questionnaire. Consequently, experts were informed of latest responses and were able to agree or disagree with the first consensus.

\subsection{Results}

According to the main drivers and stakeholders involved, the results obtained in the first round of the questionnaire are described in Table 4 and Table 5, where the CV of each driver is showed. Table 4 includes the drivers with CV lower than 20\%, so it exposes the drivers with the highest agreement in the first questionnaire. Moreover, Table 5 includes the results of the two rounds, where the $\mathrm{CV}$ of each driver for both questionnaires and the difference between them is showed, helping us to identify the drivers that have demonstrated a higher consensus after the second round.

Both questionnaires included open questions in order to allow participants to better express their opinions. Table 6 details others drivers of USR proposed by the experts. Table 7 considers the barriers related to the participation in university activities and the barriers to include USR into strategic management. According to the inclusion of the USR as objective into the strategic plan, interesting views were mentioned by the experts. Thus, to complete the quantitative information, they are presented in Table 8. Finally, Table 9 shows the experts' opinions about the importance to incorporate USR into the strategic plan, with the purpose of support the transcendence of the USR into the university management system.

\subsection{Discussion of results}

Results showed that drivers related to students training have a greater relationship with USR, demonstrating that expectations and needs of students are a priority to HEI. It is observed on the results that the most accepted drivers are to promote the ethical way to investigate among students, and the ability to work under a code of ethics (see Table 4).

Among the drivers best ranked by experts are the commitment of teachers to incorporate social and civic competences as part of the vocational training, the promotion of social development as part of the academic program, the understanding of the social responsibilities of the fields of study, and the promotion of ethical training linked to the professional profile. These drivers are highly related to other studies about the ethical way to investigate and the production of research that could solve community problems (Owen et al. 2012; PRME 2007; UNESCO 1998a; GUNI 2017). Also, volunteering is a highly-ranked driver because of its positive effects on students (Cronje 2015). Consequently, hypothesis H1 (main drivers that experts identify as part of USR are those related to students training) was accepted, given that the highest approval of the experts is on the area of students training.

Furthermore, the results showed the importance of drivers such as: equal opportunities for people with disabilities, acquisition of ability to interact with people of different cultures, promotion of solidarity, and university cooperation and gender equality (see Table 
4). These drivers are related to inclusive HEI perception (De la Cruz \& Sasia 2008), and they are connected with transformational approach, which links HEI work to social issues. The promotion of the social development driver is related to university social leadership (Kliksberg 2009; Chomsky et al. 2002; UNESCO 1998b). These results agreed with the university role of helping the transformational relationship on development process (Morris et al. 2011), and with the need of university actions on gender equality (Jacobs 1996; Teelken \& Deem 2013). The promotion of entrepreneurial projects involving the participation of society seems to be among the principal drivers to USR (see Table 4). This could be explained with the fact that universities are identified as a driver of entrepreneurial society (Ratten 2017).

As we can observe in Table 5, CV was reduced, which means higher consensus. Consequently, the objective of the Delphi method focused on reducing the dispersion of opinions was achieved. It is also observed that fostering relationships with national and international universities is not well accepted as driver by researchers on USR, but it was highly accepted among academic authorities (see Table 5). On the other hand, transparency and accountability driver has a low acceptance, in spite of the great efforts made by institutions such as GRI, ISO26000 and PRME. Additionally, the driver related to promote a healthy and balanced diet has the lowest acceptance among experts (see Table 5). This could be a topic for further research.

The results about barriers to include USR on strategic planning (see Table 7) indicated that the main barriers are: lack of involvement of the university community, lack of engagement of team leaders, poor communication, and lack of political will. In this line, experts made emphasis to boost engagement of university community as a key part of the success of social responsibility. These results agreed with the definition of USR as a participative dialog with the society, pursuing a sustainable development (Linares et al. 2012). Likewise, the results about a lack of engagement matched with the "doing" step of developing a strategic plan. This step includes implementation, communication and alignment, which require a high level of engagement among university community, especially among people in charge (Hrebiniak 2007). This is aligned with the experts' opinions about disagreements in the governance system, between objectives and individual responsibilities.

Also, Table 6 shows that there is a consensus among experts about considering dia$\log$, participation and engagement as key drivers. Taking into account the aspects mentioned above, hypothesis H2 (barriers of the inclusion of USR on strategic planning are related with lack of university community engagement) was accepted, since the barriers of inclusion of USR on strategic planning are related with a lack of university community engagement.

On the other hand, results about the inclusion of USR on strategy (see Table 8) indicated that its transversal inclusion is more acceptable, which suggests immersion of USR on all university areas. This is justified by the experts considering the benefits to all stakeholders. Furthermore, the experts highlighted the importance of USR as core of university activities by attending stakeholder's demands. Also USR was perceived as an internal strength, and as a philosophy of action (see table 9). On other words, USR appeared as part of the mission, since HEI mission is considered as the broadest word used to describe a university's purpose (Allen 1988). These results are supported by other studies on the high expectation of HEI's social mission as public organizations (Vázquez et al. 2016). Consequently, hypothesis H3 (inclusion of USR into the university strategies is most accepted 
into university missions) was accepted due to the recognition of USR into the university strategy as part of the mission.

Finally, the results suggested that USR makes HEI sustainable, and that USR implementation could provide a series of benefits to all stakeholders due to the university obligation to react responsibly to social demands.

\section{CONCLUSIONS}

The importance of this research lays on the relevance of the University Social Responsibility. The necessity to promote ethical behaviours requires greater commitment from Higher Education Institutes and their academic authorities, due to their scope of influence, universities represent a great opportunity for social progress.

Nevertheless, a greater understanding and engagement is necessary among stakeholders and especially amongst academic authorities due to their responsibility for carrying out strategies to implement drivers to University Social Responsibility. In this line, efforts to make it work inside universities represent an opportunity of social development. Hence, in this research, three main aspects were studied: 1) drivers to achieve social responsibility, 2) barriers to include University Social Responsibility in strategic planning, and 3) the position of social responsibility for strategic planning.

The Delphi method was used to carry out this analysis. This technique consists of consulting a group of experts about a specific area of interest, and gaining its value from the holistic point of view of the group. Due to its nature, the quality of Delphi method relies on the experts' level of knowledge and experience. In this work, two groups have been selected, the first group includes researchers in University Social Responsibility and the second group embraces authorities selected by years of experience and high positions in university management; thus, experts such as university chancellors were included.

This work has presented three hypotheses. The first one proposed that the main drivers to University Social Responsibility are related to students' training, which has been accepted to make the highest approval of drivers related to academic training, especially ethical ways of investigating and working under a code of ethics. The second hypothesis proposed that barriers including University Social Responsibility for strategic planning are related to a lack of university community engagement. This hypothesis was accepted since community engagement and lack of communication were the main barriers including social responsibility into strategic planning. The third hypothesis proposed that the inclusion of University Social Responsibility as a strategy is more accepted in university missions than as a specific objective. This hypothesis was accepted due to the fact that experts highlight the University Social Responsibility as a way to act in all university activities.

Although research construction was carefully prepared, we are aware of the limitations as well as of the improvement aspects in the development of the research method. First of all, the expert panels were chosen meticulously by their high knowledge of University Social Responsibility and by their key positions as academic authorities. Both groups are experts in busy schedules and the questionnaire responses were quite time-consuming (more than seven weeks for the first round and three weeks for the second round). Thus, the main method limitations emerge from their tedious progress. Also, the nature of the method cause to concentrate only on those aspects that obtained a consensus, causing a low attention to those far-from-average opinions, may be of great interest of study. 
To sum up, it is evident that universities need to get more involved in community activities and create effective strategies together with a plan, a timeline and specific involved stakeholders, and must cover all university activities. To divide the university activities into sections (university management, academic training, responsible research, university staff, and social development) and to coordinate specific drivers (based on the demands of each group of stakeholders) could be the beginning of an organized social responsibility.

\section{ACKNOWLEDGMENTS}

This work has been supported by federal financing of National Council of Science and Technology (CONACYT) of Mexico. Also, this work would not have been possible without the collaboration of the experts implicated in the study. Thanks to their collaboration this work gains its value.

\section{REFERENCES}

Alexander, L.D., 1985. Successfully Implementing Strategic Decisions. Long Range Planning, 18(3), pp.91-97.

Allen, M., 1988. The goals of universities, UK: SRHE \& Open University Press.

Andriof, J. \& McIntosh, M., 2001. Perspectives on corporate citizenship Sheffield:,

Araya, D. \& Peters, M.A., 2010. Education in the creative economy : knowledge and learning in the age of innovation, New York: Peter Lang.

Armstrong, R., 1987. The midpoint on a Five-Point Likert-Type Scale. Perceptual and Motor Skills, 64(2), pp.359-362.

Atakan, M. \& Eker, T., 2007. Corporate identity of a socially responsible university-a case from the Turkish higher education sector. Journal of Business Ethics, 76(1), pp.55-68.

Berry, M., 1986. Logique de la connaissance et logique de l'action Audet, M., Quebec City.

Brown, E. \& Cloke, J., 2009. Corporate social responsibility in Higher Education. ACME: An International e-Journal for Critical Geographies, 8(3), pp.474-483.

Burrows, J., 1999. Going beyond labels: A framework for profiling institutional stakeholders. Contemporary Education, 70(4), pp.5-10.

Chomsky, N., Gomez, J. \& Domenech, A., 2002. Los límites de la globalización. Ariel, Barcelona, España.

Cronje, 2015. The effects of volunteering on student volunteers. Progressio: South African Journal for Open and Distance Learning Practice, 37(2), pp.1-20.

Dalkey, N. \& Helmer, O., 1963. An Experimental Application of the Delphi Method to the use of experts. Management Science, 9(3), pp.458-467.

Dana, L.. \& Dana, T.E., 2005. Expanding the scope of methodologies used in entrepreneurship research. Int. J. Entrepreneurship and Small Business, 2(1), pp.79-88.

Dana, L.. \& Dumez, H., 2015. Qualitative research revisited: epistemology of a comprehensive approach. Int. J. Entrepreneurship and Small Business, 26(2), pp.154-170.

Delbecq, A.L., A.H., V. de V. \& Gustafson, D.., 1975. Group Techniques for Program Planning: A Guide to Nominal and Delphi Processes. Scott, Foresman and Co., Glenview, IL.

Domínguez, M., 2009. Responsabilidad social universitaria. Humanismo y Trabajo Social. Humanismo y Trabajo Social, 8.

Dumay, J.C., Guthrie, J. \& Farneti, F., 2010. GRI Sustainability Reporting Guidelines for Public and Third Sector Organizations. Public Management Review, 12(4), pp.531-548.

Fink, A. et al., 1991. Consensus Methods: Characteristics and Guidelines for Use RAND. 1991.

Francis, J., 2011. The functions and norms that drive university student volunteering. 
International Journal of Nonprofit and Voluntary Sector Marketing, 16(1), pp.1-12.

Gaete, R., 2011. La responsabilidad social universitaria como desafío para la gestión estratégica de la Educación Superior: El caso de España. Revista de Educacion, 355, pp.109-133. Available at: http://www.scopus.com/inward/record.url?eid=2-s2.080052565265\&partnerID=tZOtx3y1.

García, M. \& Suárez, M., 2013. El método Delphi para la consulta a expertos en la investigación científica. Revista Cubana de Salud Pública, 39(2), pp.253-267.

George, D. \& Mallery, P., 2003. SPSS for Windows step by step: A simple guide and reference. 11.0 .

Gibbons, J., 2006. Employee Engagement: A Review of Current Research and Its Implications. In The Conference Board. New York, NY., pp. 1-21.

Gibbs, G. \& Coffey, M., 2016. The Impact Of Training Of University Teachers on their Teaching Skills, their Approach to Teaching and the Approach to Learning of their Students. Active Learning in Higher Education, 5(1), pp.87-100.

Gnyawali, D. \& Fogel, D., 1994. Environment for Entrepreneurship Development, Key Dimensions and Research Implications. Entrepreneurship Theory and Practice, 18, pp.4362.

GRI, 1997. Global Reporting Initiative. Available at: https://www.globalreporting.org/information/sustainability-reporting/Pages/default.aspx [Accessed February 11, 2016].

GUNI, 1999. Global University Network for Innovation. Available at: http://www.guninetwork.org/mission-and-objectives [Accessed February 11, 2016].

GUNI, 2017. Higher Education in the World 6. Towards a Socially Responsible University: Balancing the Global with the Local, Girona.

Hasson, F., Keeney, S. \& McKenna, H., 2000. Research guidelines for the Delphi survey technique. Journal of Advanced Nursing, (32), pp.1008-1015.

Hernández, M., 2007. La responsabilidad social dentro del sector público. Ekonomiaz: Revista vasca de Economía, 65, pp.84-107.

Hines, J., Hungerford, H. \& Tomera, A., 1987. Analysis and synthesis of research on responsible environmental behaviour: a meta-analysis. Journal of environmental Education, 18(2).

Hrebiniak, L.G., 2007. Making strategy work Whartoon S., New Jersey: Pearson Education, Inc.

Hunt, C. et al., 1997. Strategic Planning for Private Higher Education. Binghamton, NY: Haworth.

ISO 26000, 2014. ISO 26000: Responsabilidad social en la universidad. 21 enero. Available at: http://www.isotools.org/2014/01/21/iso-26000-responsabilidad-social-en-la-universidad/ [Accessed March 9, 2015].

Jacobs, J.A., 1996. Gender Inequality and Higher Education. Annual Review of Sociology, 22, pp.153-185.

Jongbloed, B., Jurgen, E. \& Salerno, C., 2008. Higher education and its communities: Interconnections, interdependencies and a research agenda. High Educ, 56, pp.303-324.

Keeney, S., Hasson, F. \& McKennaH.P., 2001. A critical review of the Delphi technique as a research methodology for. Nursing International Journal of Nursing, 38, pp.195-200.

Kliksberg, B., 2009. Responsabilidad social corporativa en tiempos de crisis. Harvard Deusto Business Review, ( $\left.{ }^{\circ} 180\right)$, pp.38-45.

De la Cruz, C. \& Sasia, P., 2008. La responsabilidad de la universidad en el proyecto de construcción de una sociedad. Revista Educación Superior y Sociedad, 13(2), pp.17-52. 
Available at: http://unesdoc.unesco.org/images/0018/001820/182067s.pdf.

Larrán Jorge, M. \& Andrades Peña, F.J., 2015. Análisis de la responsabilidad social universitaria desde diferentes enfoques teóricos. Revista Iberoamericana de Educación Superior, 6(15), pp.91-107.

Levin, R. \& Rubin, D., 2004. Estadística para administración y economía Pearson Ed., Edo de México.

Linares, Y., Godoy, M.R. \& Sáez, B., 2012. La responsabilidad social universitaria: una contribución al desarrollo de las comunidades. Academia, 11(23), pp.215-223.

Linstone, H. \& Turoff, M., 1975. The Delphi Method: Techniques and Applications. AddisonWesley, Reading, MA.

Llinàs, X., Girotto, M. \& Solé, F., 2011. University strategic management and the efficacy of the managerial tools: The case of the Spanish universities [La dirección estratégica universitaria y la eficacia de las herramientas de gestión: El caso de las universidades españolas]. Revista de Educacion, 355, pp.33-54. Available at: http://www.scopus.com/inward/record.url?eid=2-s2.080052570584\&partnerID=40\&md5=591657b273645697946145c203eeea37.

Lumby, J., 1999. Strategic Planning in further education. The business of value. Education Management \& Administration, 27(1), pp.71-83.

Mitchell, R. K., Agle, B. R., \& Wood, D.J., 1997. Toward a theory of stakeholder identification and salience: Defining the principle of who and what really counts. Academy of Management Review, 22(4), pp.853-886.

Morgan, G., 1983. Beyond Method: Strategies for Social Research Sage., Newbury Park, California.

Morris, M.H. et al., 2011. Inner city engagement and the university: Mutuality, emergence and transformation. Entrepreneurship \& Regional Development: An International Journal, 23(5-6), pp.287-315.

Murphy, M.K. et al., 1998. Consensus development methods and their use in clinical guideline development. Health Technology Assessment, 2(3).

Murray, C. \& Lombardi, C., 2010. The Effects of Disability-Focused Training on the Attitudes and Perceptions of University Staff. Remedial and Special Education, 32(4), pp.290-300.

Navarro-Galera, A. et al., 2014. Corporate Social Responsibility in Local Government in the United Kingdom and Ireland. Innovar Journal, 24(54), pp.89-105.

Navarro, A., Alcaraz, F. \& Ortiz, D., 2010. La divulgación de información sobre responsabilidad corporativa en administraciones públicas: Un estudio empírico en gobiernos locales. Revista de Contabilidad, 13(2), pp.285-314.

Neave, G., 2000. The universities' responsibilities to society, Oxford: Pergamon.

Owen, R., Macnaghten, P. \& Stilgoe, J., 2012. Responsible research and innovation: From science in society to science for society, with society. Science and Public Policy, 39(6), pp.751-760.

Palalić, R. et al., 2017. Entrepreneurial intentions of university students: a case-based study. Journal of Enterprising Communities: People and Places in the Global Economy, 11(3), pp.393-413.

Peng, W. \& Littlejohn, D., 2001. Organisational Communication and Strategy Implementation-A primary inquiry. International Journal of Contemporary Hospitality, 13, pp.360-363.

Planellas, M. \& Muni, A., 2015. El libro de las decisiones estratégicas CONECTA.,

Porter, M.E. \& Kramer, M.R., 2011. Creating shared value. Harvard Business Review. 
Powell, C., 2003. The Delphi technique : myths and realities. Journal of Advanced Nursing, 41(4), pp.376-382.

PRME, 2007. Principles for Responsible Management Education (PRME),

Quinn, J., 1980. Strategies for Change: Logical Incrementalism. Sloan Management Review.

Ratten, V., 2017. Entrepreneurial universities: the role of communities, people and places. Journal of Enterprising Communities: People and Places in the Global Economy, 11(3), pp.310-315.

Reavill, L., 1998. Quality assessment, total quality management and the stakeholders in the UK higher education system. Managing Service Quality: An International Journal, 8(1), pp.5563.

Rexhepia, G., Bexhetic, S. \& Kurtishib, G., 2013. Corporate Social Responsibility (CSR) and Innovation The drivers of business growth? Procedia - Social and Behavioral Sciences, 75, pp.532-541.

Sánchez, I. \& Mainardes, E., 2016. University social responsibility: a student base analysis in Brazil. International Review on Public and Nonprofit Marketing, 13(2), pp.151-169. Available at: http://dx.doi.org/10.1007/s12208-016-0158-7.

Teelken, C. \& Deem, R., 2013. All are equal, but some are more equal than others: managerialism and gender equality in higher education in comparative perspective. Comparative Education, 49(4), pp.520-535.

Tinker, A., Merino, B. \& Neimark, M., 1982. The normative origins of positive theories. Accounting Organization and Society, 7, pp.167-200.

UNESCO, 1998a. Autonomía, responsabilidad social y libertad académica. In VII Conferencia Mundial de Educación. Paris Francia.

UNESCO, 1998b. Declaración Mundial sobre la Educación Superior en el Siglo XXI: Visión y Acción. In Conferencia Mundial Sobre la Educación Superior. UNESCO. París, Francia.

Vallaeys, F., 2013. La Responsabilidad Social Universitaria: ¿Cómo entenderla para quererla y practicarla? Revista servicio comunitario, 2(1).

Vallaeys, F., 2008. Responsabilidad Social Universitaria: una nueva filosofía de gestión ética e inteligente para las universidades. Revista Educación Superior y Sociedad, 13(2), pp.191220.

Vallaeys, F., De la Cruz, C. \& Sasia, P., 2009. Responsabilidad Social Universitaria. Manual primeros pasos, México D.F., México.: McGraw Hill.

Vasilescu, R. et al., 2010. Developing university social responsibility: A model for the challenges of the new civil society. Procedia-Social and Behavioral Sciences, 2(2), pp.4177--4182.

Vázquez, J.L., Aza, C. \& Lanero, A., 2016. Citizens' perceptions on social responsibility in public administration organizations: a case study on Spain. Transylvanian Review of Administrative Sciences, (48), pp.166-183.

Velandia, C. \& Girotto, M., 2015. Strategic management in universities: A conceptual framework based in ibero-american higher education systems, Springer.

Welch, S. \& Comer, J., 1988. Quantitative methods for public administration: techniques and applications Brooks/Col., la Universidad de Virginia.

Williams, C.C., Martinez-Perez, A. \& Kedir, A.M., 2016. Informal Entrepreneurship in Developing Economies: The Impacts of Starting Up Unregistered on Firm Performance. Entrepreneurship Theory and Practice.

Wooldridge, B. \& Floyd, S.W., 1990. The strategy process, middle management involvement, 
and organizational performance. Strategic Management Journal, 11(3), pp.231-241. 
Figure 1: Delphi method applied to the study of University of Social Responsibility.

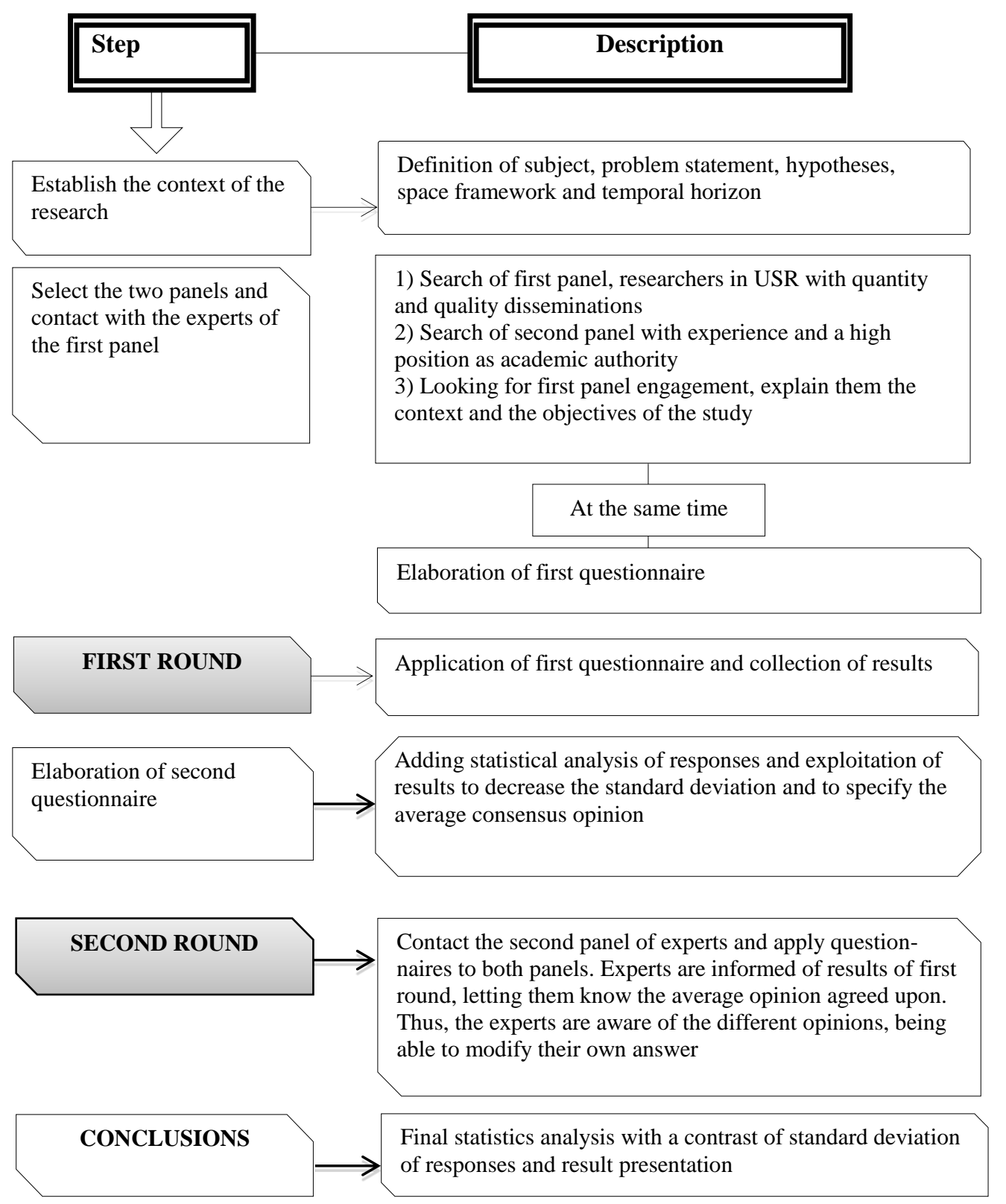

Source: Own creation based on Delphi method (Dalkey \& Helmer 1963). 
Figure 2: Questionnaire content

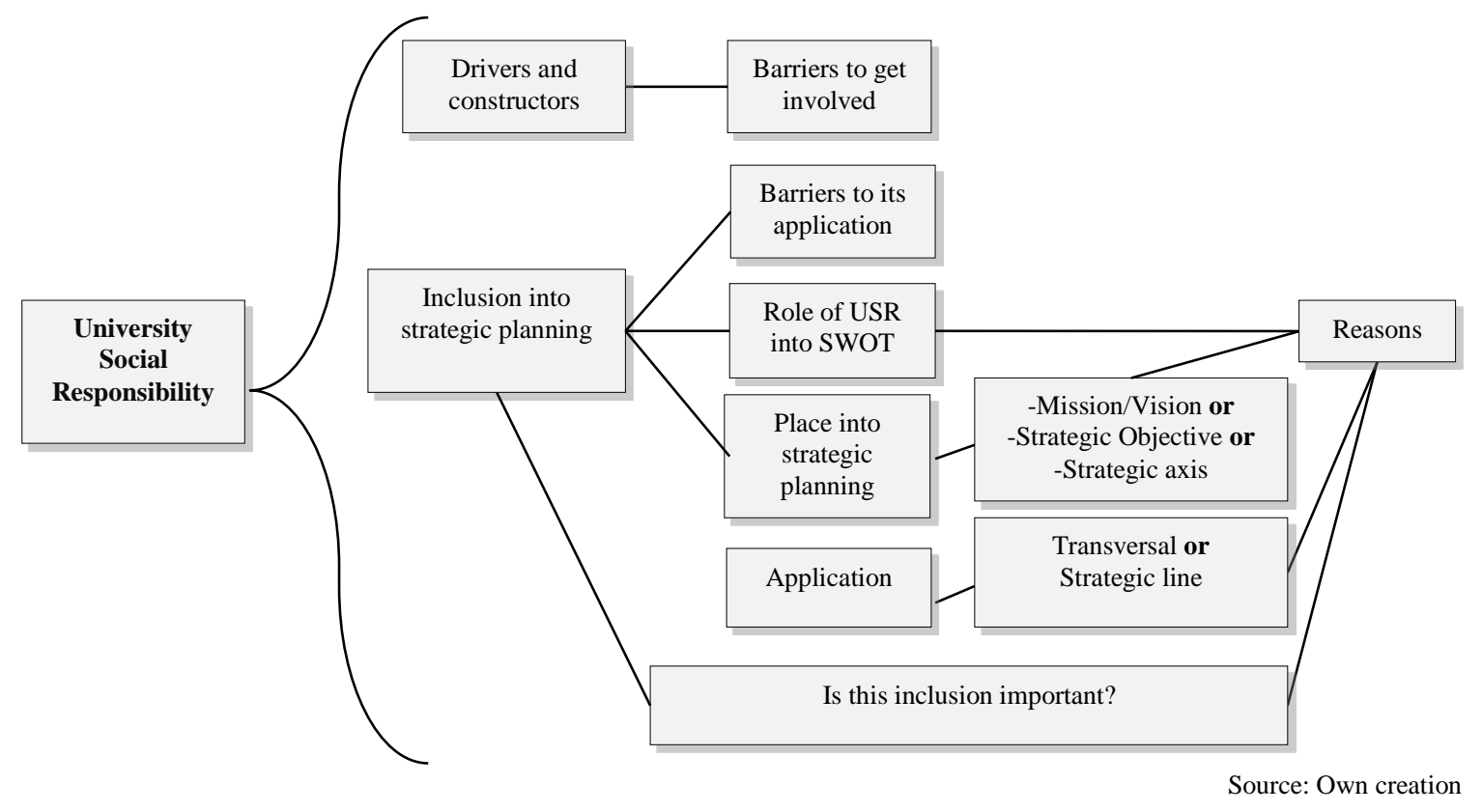


Table 1: Drivers that lead to University Social Responsibility

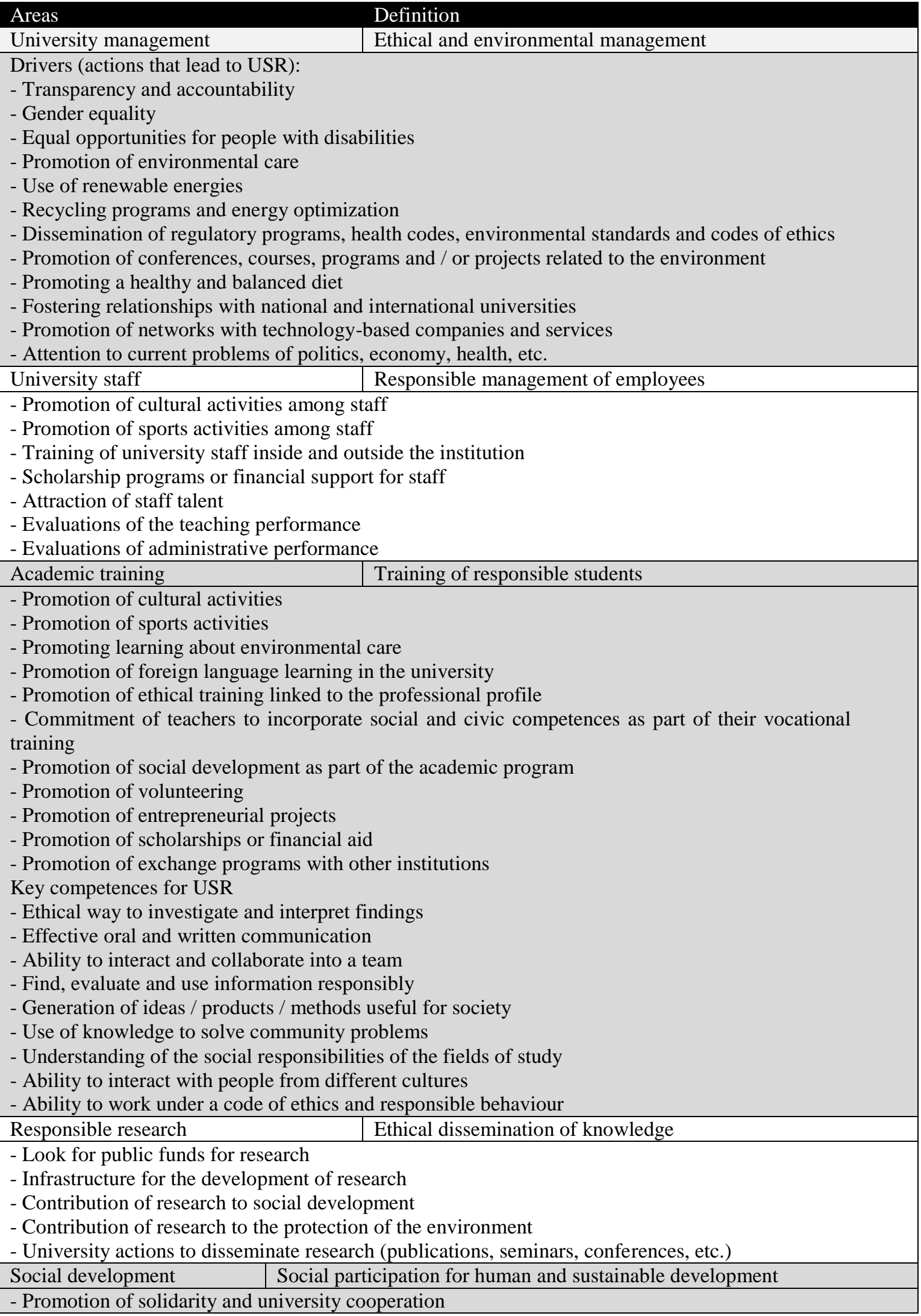




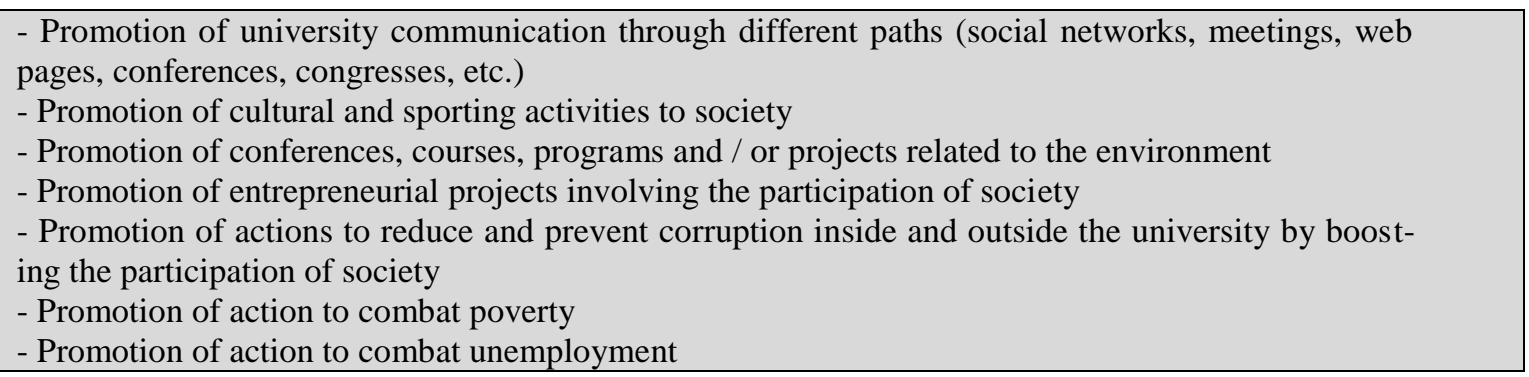

Table 2: Alpha of Cronbach interpretation of two rounds

\begin{tabular}{|l|l|l|l|l|l|l|l|}
\hline \multicolumn{2}{|c|}{$\begin{array}{l}\text { Alfa of Cronbach of first } \\
\text { questionnaire }\end{array}$} & $\begin{array}{l}\text { Items } \\
\text { tested }\end{array}$ & \multicolumn{2}{c|}{$\begin{array}{l}\text { Alfa of Cronbach of second } \\
\text { questionnaire }\end{array}$} & $\begin{array}{l}\text { Items } \\
\text { tested }\end{array}$ \\
\hline $\begin{array}{l}\text { University man- } \\
\text { agement }\end{array}$ & .98 & Excellent & 12 & .93 & Excellent & 13 \\
\hline University staff & .89 & Good & 7 & .73 & Acceptable & 7 \\
\hline $\begin{array}{l}\text { Academic train- } \\
\text { ing }\end{array}$ & .94 & Excellent & 20 & .60 & Questionable & 5 \\
\hline $\begin{array}{l}\text { Responsible } \\
\text { research }\end{array}$ & .97 & Excellent & 5 & .75 & Acceptable & 4 \\
\hline $\begin{array}{l}\text { Social develop- } \\
\text { ment }\end{array}$ & .87 & Good & 8 & .86 & Good & 5 \\
\hline
\end{tabular}

Table 3: Degree of accuracy of Coefficient of Variation

\begin{tabular}{|l|l|}
\hline Coefficient of Variation & Precision \\
\hline Until $10 \%$ & Precise \\
\hline From 11 to $20 \%$ & Acceptable \\
\hline Greater than $20 \%$ & Unconfinable \\
\hline
\end{tabular}

Table 4: Drivers of first round with highest agreement and their Coefficient of Variation.

\begin{tabular}{|l|c|}
\hline Actions that lead universities to USR & $\begin{array}{c}\text { Coefficient } \\
\text { of Variation }\end{array}$ \\
\hline Ethical way to investigate and interpret findings & 0 \\
\hline Ability to work under a code of ethics and responsible behaviour & 8,45 \\
\hline $\begin{array}{l}\text { Equal opportunities for people with disabilities } \\
\text { training }\end{array}$ & \\
\hline Promotion of social development as part of the academic program & 11,07 \\
\hline Understanding of the social responsibilities of the fields of study & \\
\hline Ability to interact with people of different cultures & \\
\hline Promotion of solidarity and university cooperation & \\
\hline Promotion of ethical training linked to the professional profile & \\
\hline Promotion of volunteering & \\
\hline Find, evaluate and use information responsibly & \\
\hline Promoting action to combat poverty & \\
\hline Promoting action to combat unemployment & \\
\hline
\end{tabular}




\begin{tabular}{|l|l|}
\hline Communication between the university community & \multirow{2}{*}{12,17} \\
\hline Integration of all areas of university management & \\
\hline Training of university staff inside and outside the institution & \\
\hline Effective oral and written communication & \multirow{2}{*}{17,5} \\
\hline Ability to interact and collaborate into a team & \\
\hline Gender equality & \\
\hline Generation of ideas / products / useful methods for society & \multirow{2}{*}{18,59} \\
\hline Use of knowledge to solve community problems & \\
\hline $\begin{array}{l}\text { Promotion of actions to reduce and prevent corruption inside and outside the university } \\
\text { boosting the participation of society }\end{array}$ & \\
\hline Promotion of scholarships or financial aid & \\
\hline Public funds for research & \\
\hline Infrastructure for the development of research & \\
\hline Promotion of entrepreneurial projects involving the participation of society & \\
\hline
\end{tabular}

Table 5: Comparison between Coefficients of Variations of the drivers of the second round.

\begin{tabular}{|c|c|c|c|c|}
\hline \multirow{2}{*}{ Area } & \multirow{2}{*}{ Drivers that lead universities to USR } & \multicolumn{2}{|c|}{ Coefficient of Variation } & \multirow{2}{*}{$\begin{array}{l}\text { Differences } \\
\text { between } \mathrm{CV}\end{array}$} \\
\hline & & First Round & $\begin{array}{l}\text { Second } \\
\text { Round }\end{array}$ & \\
\hline \multirow{9}{*}{$\begin{array}{l}\text { University } \\
\text { management }\end{array}$} & Transparency and accountability & 27.22 & 25.72 & 1.5 \\
\hline & $\begin{array}{l}\text { Promotion of networks with technology- } \\
\text { based companies and services }\end{array}$ & 30.50 & 25.08 & 5.42 \\
\hline & $\begin{array}{l}\text { Attention to current problems of politics, } \\
\text { economy, health, etc. }\end{array}$ & 22.36 & 18.85 & 3.51 \\
\hline & Recycling programs and energy optimization & 28.06 & 21.71 & 6.35 \\
\hline & Promoting healthy and balanced diet & 31.62 & 27.72 & 3.9 \\
\hline & Promoting environmental care & 27.22 & 21.06 & 6.16 \\
\hline & $\begin{array}{l}\text { Dissemination of regulatory programs, health } \\
\text { codes, environmental standards and codes of } \\
\text { ethics }\end{array}$ & 27.95 & 19.72 & 8.23 \\
\hline & Use of renewable energies & 27.95 & 21.06 & 6.89 \\
\hline & $\begin{array}{l}\text { Fostering relationships with national and } \\
\text { international universities }\end{array}$ & 30.50 & 18.72 & 11.78 \\
\hline \multirow{3}{*}{ University staff } & Promotion of cultural activities among staff & 25.65 & 23.80 & 1.85 \\
\hline & Evaluations of the teaching performance & 22.36 & 18.72 & 3.64 \\
\hline & Evaluations of administrative performance & 22.36 & 20.43 & 1.93 \\
\hline \multirow{2}{*}{$\begin{array}{l}\text { Academic } \\
\text { training }\end{array}$} & Promoting learning about environmental care & 25.65 & 14.92 & 10.73 \\
\hline & $\begin{array}{l}\text { Promotion of exchange programs with other } \\
\text { institutions }\end{array}$ & 23.60 & 16.22 & 7.38 \\
\hline $\begin{array}{l}\text { Research and } \\
\text { dissemination } \\
\text { of knowledge }\end{array}$ & $\begin{array}{l}\text { Contribution of research to the protection of } \\
\text { the environment }\end{array}$ & 28.06 & 24.30 & 3.76 \\
\hline
\end{tabular}




\begin{tabular}{|l|l|l|l|l|}
\hline $\begin{array}{l}\text { Social devel- } \\
\text { opment }\end{array}$ & $\begin{array}{l}\text { Promotion of conferences, courses, programs } \\
\text { and / or projects related to the environment }\end{array}$ & 23.60 & 21.88 & 1.72 \\
\hline
\end{tabular}

Table 6: Drivers that lead to University Social Responsibility proposed by experts in the two rounds.

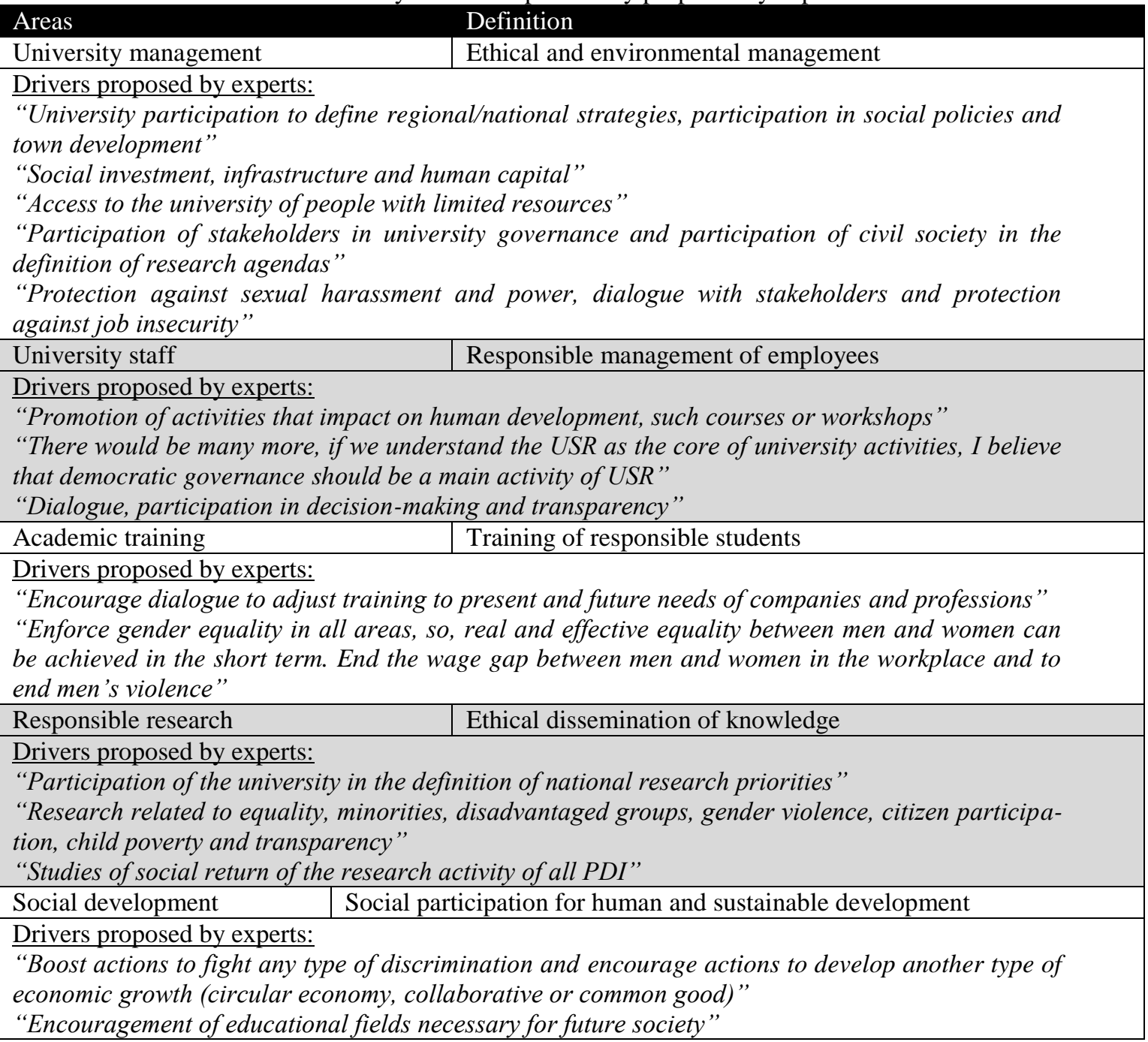

Table 7: Barriers to enroll into USR and to incorporate it into strategic planning proposed by experts in the two rounds.

\begin{tabular}{|c|c|}
\hline \multicolumn{2}{|l|}{ Barriers } \\
\hline $\begin{array}{l}\text { Barriers to participate in USR activities: } \\
\text {-Lack of time } \\
\text {-Lack of interest of university community } \\
\text {-Lack of dissemination and promotion by its } \\
\text { organizers } \\
\text {-Cost of attendance or participation }\end{array}$ & $\begin{array}{l}\text { Barriers proposed by experts: } \\
\text { "Misalignment in the governance system: } \\
\text { lack of relationship between institutional } \\
\text { objectives and individual responsibili- } \\
\text { ties" } \\
\text { "Lack of relevance of the issues" } \\
\text { "Lack of involvement of the university } \\
\text { community" } \\
\text { "The absence of structured and rational } \\
\text { programs, coordinated at the all universi- } \\
\text { ty levels" } \\
\text { "Do not specify time, compulsory", }\end{array}$ \\
\hline
\end{tabular}




\begin{tabular}{|c|c|}
\hline & $\begin{array}{l}\text { "Lack of engagement of team leaders" } \\
\text { "The quality of the activities and their } \\
\text { relationship with the time needed to at- } \\
\text { tend or collaborate" } \\
\text { "The explicit and professional recogni- } \\
\text { tion of these activities" }\end{array}$ \\
\hline $\begin{array}{l}\text { Barriers to incorporate USR into strategic plan- } \\
\text { ning: } \\
\text {-Lack of engagement of university community } \\
\text {-Poor monitoring of the implementation of USR } \\
\text {-Poor communication between university com- } \\
\text { munity } \\
\text {-Poor integration of all areas of university man- } \\
\text { agement }\end{array}$ & $\begin{array}{l}\text { Barriers proposed by experts: } \\
\text { "Mainly, "lack of political will" is in fact } \\
\text { a reflection of a mismatch in the system } \\
\text { of governance: insufficient institutional } \\
\text { definition of the university" } \\
\text { "Lack of political will" }\end{array}$ \\
\hline
\end{tabular}

Table 8: Inclusion of USR into strategic plan considered by experts in the two rounds

\section{Inclusion of University Social Responsibility into Strategic Plan}

\begin{tabular}{|c|c|}
\hline Issue & Expert contribution \\
\hline $\begin{array}{l}\text { Transversal } \\
\text { inclusion }\end{array}$ & $\begin{array}{l}\text { "The USR must be transversal to the university performance, also in its strategic } \\
\text { definition" } \\
\text { "Yes, it must be implemented transversally because it is a common benefit" } \\
\text { "Transversally, otherwise, it would not be USR, it would be an isolated strategy" } \\
\text { "Transversal application of USR is desirable, as long it would be supervised, } \\
\text { because what is in everywhere may end up being in none" } \\
\text { "USR must include all management areas" } \\
\text { "Yes, because all of us are part of the institution and also are included in some } \\
\text { interest group and will be an important part of meeting the strategic objectives" } \\
\text { "Transversal, although, someone or some department in concrete (a line or a } \\
\text { team) should boost it and contribute to its characterization" }\end{array}$ \\
\hline $\begin{array}{l}\text { Inclusion as an } \\
\text { Objective }\end{array}$ & $\begin{array}{l}\text { "Better as a strategic line than transverse inclusion, as strategic line USR will be } \\
\text { stronger, difficult to disappear and easier to identify the responsible of its devel- } \\
\text { opment" }\end{array}$ \\
\hline $\begin{array}{l}\text { Positive fac- } \\
\text { tors that helps } \\
\text { the inclusion }\end{array}$ & $\begin{array}{l}\text { "It is important don't limit USR in aspects such as environmental, health, acces- } \\
\text { sibility ... USR should affect the core university activity, thus, USR give responses } \\
\text { to society of the university impacts of its activity of the University, as teaching, } \\
\text { research, dissemination" } \\
\text { "We have observed a positive evolution in recent years. In the strategic plans of the } \\
\text { universities as well as in their activities, there is an increasing presence of the USR" }\end{array}$ \\
\hline $\begin{array}{l}\text { Internal } \\
\text { strength }\end{array}$ & $\begin{array}{l}\text { The USR can be considered as internal strength and external opportunity. In this } \\
\text { way, it is more appropriate to incorporate it as a philosophy of action, and, the } \\
\text { satisfaction of the internal stakeholders, then proceed, to communication external- } \\
\text { ly (in some cases it may be reversed) } \\
\text { "It should be an internal policy", } \\
\text { "The university must encourage the training of social responsible community, }\end{array}$ \\
\hline
\end{tabular}




\begin{tabular}{|c|c|}
\hline & $\begin{array}{l}\text { whether if it does or not, will transform the USR into strength or into weakness" } \\
\text { "The USR is the path for the university community (understood as internal public) } \\
\text { to be involved with the university and this impacts on the reputation and external } \\
\text { visibility of universities as centers of excellence. Beyond the position in rankings } \\
\text { that only measure the reputation for the references it receives (not for what it truly } \\
\text { is and does)" } \\
\text { "True commitment to USR must emerge from the core of university, not as strate- } \\
\text { gic opportunism in the face of international markets, rankings and reputation. } \\
\text { Internal community must believe in USR, so that, it will be strategic and showed in } \\
\text { external community" } \\
\text { "It can be an competitive advantage over other institutions" } \\
\text { "The USR should be understood as strength because it is a way to manage univer- } \\
\text { sity, according to values and commitments to society and it contributes to the } \\
\text { sustainable development" } \\
\text { "Is an internal strength, because it must be within the university mission and } \\
\text { vision. In this way, the development and monitoring of the actions are strengths } \\
\text { for the university and for the society where the university develops" } \\
\text { "USR within university plans is an internal strength, committed to training, with } \\
\text { internal university processes and with society" } \\
\text { "It is an internal strength because it structures the true scope and commitment to } \\
\text { society that has placed its trust in the university" }\end{array}$ \\
\hline $\begin{array}{l}\text { External op- } \\
\text { portunity }\end{array}$ & $\begin{array}{l}\text { "The USR should be understood as something dynamic and changing according } \\
\text { to the demands of the society in which the university is part of" } \\
\text { "Is an external opportunity because society claim for USR" } \\
\text { "Because the university role in the business world could results as major im- } \\
\text { provement on university management" }\end{array}$ \\
\hline
\end{tabular}

Table 9: Importance of including USR into strategic plan considered by experts in the two rounds, Expert contribution

"So transcendent that, ideally, it should not be referred to it, since all the action of the university, in teaching, research and service to society should be based on social responsibility"

"Yes, it is what will make universities sustainable (from all points of view) and can count on the support and identification of their audiences. The USR makes universities become centers where employees and students are "proud" to belong, USR makes companies want to collaborate with them and that society respects them as centers of reference and gives them credibility"

"I do consider it transcendent, because what is planned hardly happens. As long there is no clear strategic line of USR promotion it will hardly be generated”

"Yes, it is a fundamental axis in a desirable sustainability framework"

“Yes. It will make a competitive institution and will benefits all interested parties”

"Yes, but above all as accountability to society"

"Yes, it is necessary, because it is the path of institution engagement to its employees, students and 
"Yociety"

"Of course, as long there is a real commitment of the university with the objectives of the USR of ethical and environmental character"

"Yes, because the USR is the main strategy to follow, letting the institutions become sustainable and contribute to welfare and social development. In a globalized environment students and employees will demand institutions that respond to university commitment to society beyond the obligations or "minimum" commitments that are expected of it. We will seek useful institutions for society, noncorrupt, that make us feel that we belong to them, beyond our work or academic relationship"

"Yes, because it allows a better response of the University to the society demands and a better fulfilment of its objectives" 